\title{
Chromium-saponite clay catalysts: Preparation, characterization and catalytic performance in propene oxidation
}

\author{
G. Mata ${ }^{a}$, R. Trujillano ${ }^{a}$, M.A. Vicente ${ }^{\mathrm{a}, *}$, C. Belver ${ }^{\mathrm{b}}$, \\ M. Fernández-García ${ }^{\mathrm{b}}$, S.A. Korili ${ }^{\mathrm{c}}$, A. Gil $^{\mathrm{c}}$ \\ ${ }^{a}$ Departamento de Química Inorgánica, Universidad de Salamanca, Plaza de la Merced, s/n, E-37008 Salamanca, Spain \\ ${ }^{\mathrm{b}}$ Instituto de Catálisis y Petroleoquímica, C/ Marie Curie, 2, Campus de la Universidad Autónoma de Madrid, Cantoblanco, E-28049 Madrid, Spain \\ ${ }^{\mathrm{c}}$ Departamento de Química Aplicada, Edificio Los Acebos, Universidad Pública de Navarra, Campus de Arrosadía, E-31006 Pamplona, Spain
}

Received 14 February 2007; received in revised form 15 April 2007; accepted 16 April 2007

Available online 21 April 2007

\begin{abstract}
Chromium-saponite catalysts have been prepared by two synthesis procedures. The first method consisted in the intercalation of the saponite with solutions containing aluminium and chromium oligomers with various molar ratios, while the second one consisted in the incipient wetness impregnation of alumina-pillared saponite with several chromium salts, ammonium chromate, $\mathrm{Cr}(\mathrm{II})$ acetate and $\mathrm{Cr}$ (III) nitrate. Several techniques, $\mathrm{X}$-ray diffraction, nitrogen physisorption at $-196^{\circ} \mathrm{C}$, thermogravimetric and differential thermal analysis, infrared and DR-UV-vis spectroscopies, temperature-programmed reduction and electron paramagnetic resonance spectroscopy at $-196{ }^{\circ} \mathrm{C}$, have been used to characterize and to compare the properties of the materials synthesized. The results show that the solids obtained combine the layered structure of the clay and the thermal stability given by the alumina pillars. The catalysts have been tested in the oxidation of propene, showing a catalytic behaviour according to the Mars-van Krevelen mechanism, the performance not depending on the method in which chromium was incorporated to the clay.

(C) 2007 Elsevier B.V. All rights reserved.
\end{abstract}

Keywords: Alumina-pillared clays; Chromia-alumina-pillared clays; Chromium catalysts; Propene oxidation

\section{Introduction}

Pillared interlayered clays (PILCs) are a very important family of porous solids that has been developed in the last years. The synthesis procedure includes three principal steps: (i) the preparation of polyoxocations by hydrolysis of certain multivalent cations, which under appropriate conditions give rise to cationic polymeric species, (ii) the formation of the intercalated clays by ion exchange of the original charge-compensating cations of swellable smectite clays by the polyoxocations synthesized in step (i), and (iii) the formation of the pillared clays by calcination of the intercalated clays to high temperatures, at which the metastable polyoxocations are transformed into stable oxi-hydroxidic phases, which act as pillars that support the clay layers and maintain them separated. The clay layers prevent aggregation of the metallic oxide

\footnotetext{
* Corresponding author. Tel.: +34 923 294489; fax: +34 923294574. E-mail address: mavicente@usal.es (M.A. Vicente).
}

clusters, yielding to very dispersed particles. The porous structure of the pillared clays depends on the number and the size of the pillars in the interlayer region [1-7].

Intercalation of chromium is particularly interesting, because it can form well-defined polycations, such as a dimer $\left[\mathrm{Cr}_{2}(\mathrm{OH})_{2}\left(\mathrm{H}_{2} \mathrm{O}\right)_{8}\right]^{4+}$, a trimer $\left[\mathrm{Cr}_{3}(\mathrm{OH})_{4}\left(\mathrm{H}_{2} \mathrm{O}\right)_{9}\right]^{5+}$, two tetramers, an open one $\left[\mathrm{Cr}_{4}(\mathrm{OH})_{6}\left(\mathrm{H}_{2} \mathrm{O}\right)_{11}\right]^{6+}$ and a closed one $\left[\mathrm{Cr}_{4}(\mathrm{OH})_{5} \mathrm{O}\left(\mathrm{H}_{2} \mathrm{O}\right)_{10}\right]^{5+}$, or even a hexameric species [8-13]. These species coexist in $\mathrm{Cr}$-speciation diagram with the monomer $\left[\mathrm{Cr}\left(\mathrm{H}_{2} \mathrm{O}\right)_{6}\right]^{3+}$, and we may refer to all them with the general term "Cr-polycations", although the last one obviously is not a polymeric species. Aluminium can easily be polymerised to form the well-known polycation $\left[\mathrm{Al}_{13} \mathrm{O}_{4}\right.$ $\left.(\mathrm{OH})_{24}\left(\mathrm{H}_{2} \mathrm{O}\right)_{12}\right]^{7+}$, in short $\mathrm{Al}_{13}$, very efficient for the intercalation of clays [14-16]. Alumina-pillared clays are thus wellknown, easy to prepare and very stable [1-7]. The joint hydrolysis of $\mathrm{Al}(\mathrm{III})$ and $\mathrm{Cr}(\mathrm{III})$ has as a result the incorporation of two elements to the structure of the clay [17-20]. Cointercalation can be carried out in a relatively easy way by the joint hydrolysis of the two elements, followed by the addition of 
the solution containing the polymerized cations to the clay. Although it has been claimed that $\mathrm{Cr}^{3+}$ cations may be incorporated in the hydrolysis to the structure of $\mathrm{Al}_{13}$ units [20,21], no enough evidence of such mixed species has been found, and each cation may form its own polymeric species.

Chromium is an interesting metal for catalytic applications because of the variety of its oxidation states [22]. Chromium catalysts have been used in several reactions with environmental applications, such as the combustion of volatile organic compounds (VOCs) [23,24] and Cl-VOCs [25], and DeNOx reactions [26]. Only in a few cases these catalysts are based in clay supports [24,27]. Natural clays are not as common catalyst supports as alumina, silica, zeolites or carbon. The use of pillared clays, because of their relatively long preparation procedure, is justified if very specific catalysts are obtained [28,29].

In the present paper, the preparation, characterization and catalytic behaviour of several chromia-saponite catalysts are reported. The samples have been prepared by co-pillaring of saponite with aluminium- and chromium-polycations, at various $\mathrm{Al} / \mathrm{Cr}$ ratios and by impregnation of alumina-pillared saponite with various chromium precursors. The pillared samples were evaluated as catalysts in the oxidation of propene, chosen as a common hydrocarbon test in exhaust treatments [30,31].

\section{Experimental}

\subsection{Raw materials and preparation of the catalysts}

The clay used in this work was a saponite from Yunclillos (Toledo, Spain), kindly supplied by TOLSA (Madrid, Spain). The raw material was purified by dispersion in water, careful decantation and extraction of the fraction with particle size smaller than $2 \mu \mathrm{m}$. The structural formula of purified saponite on the basis of an unit cell, 22 oxygen atoms, based on the chemical analysis given in Table 1 , was found to be $\left[\mathrm{Si}_{7.348}\right.$

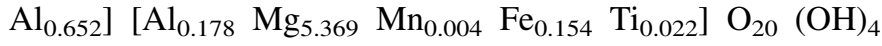
$\left[\mathrm{Ca}_{0.096} \mathrm{Na}_{0.066} \mathrm{Mg}_{0.230} \mathrm{~K}_{0.081}\right]$. The cation exchange capacity (CEC) was 0.99 mequiv/g, the basal spacing $13.8 \AA$ and the BET specific surface area $169 \mathrm{~m}^{2} / \mathrm{g}$.

Saponite was intercalated with chromium, aluminium, and solutions containing both elements. Intercalation with chromium polycations was carried out following a procedure described previously [32,33]. According to this procedure,
$30 \mathrm{mmol}$ of $\mathrm{CrCl}_{3} \cdot 6 \mathrm{H}_{2} \mathrm{O}$ (Aldrich, purissimum) were dissolved in water, and hydrolysed with $1 \mathrm{~mol} / \mathrm{dm}^{3} \mathrm{NaOH}$ (Panreac, purissimum), at a $\mathrm{OH}^{-} / \mathrm{Cr}^{3+}$ mole ratio equal to 2.0. The solution thus obtained was aged for $72 \mathrm{~h}$ so that polymerisation took place and then added to a previously prepared suspension of saponite in water at a ratio of $5.0 \mathrm{mmol}_{\mathrm{Cr}} / \mathrm{g}_{\text {clay }}$. The resulting slurry was left under stirring for $72 \mathrm{~h}$ to favour cation exchange, and then washed by dialysis until absence of chloride. The intercalated solid was separated by centrifugation and dried at $70{ }^{\circ} \mathrm{C}$ for $16 \mathrm{~h}$. Finally, it was heated at $1{ }^{\circ} \mathrm{C} / \mathrm{min}$ up to $500{ }^{\circ} \mathrm{C}$ in an oven and calcined for $2 \mathrm{~h}$.

Intercalation with aluminium polycations was carried out by a similar procedure [15,16]. First, $\mathrm{AlCl}_{3} \cdot 6 \mathrm{H}_{2} \mathrm{O}$ (Panreac, purissimum) was dissolved in water and hydrolysed with $1 \mathrm{~mol} / \mathrm{dm}^{3} \mathrm{NaOH}$ (Panreac, purissimum), at a $\mathrm{OH}^{-} / \mathrm{Al}^{3+}$ mole ratio equal to 2.2. The resulting solution was left under vigorous stirring for $24 \mathrm{~h}$ so that aluminium polycations $\left(\mathrm{Al}_{13}\right)$ were formed, and then added to a clay suspension, at a ratio of $5 \mathrm{mmol}_{\mathrm{Al}^{3+}} / \mathrm{g}_{\text {clay }}$. The slurry was aged under stirring for $24 \mathrm{~h}$, and then washed by dialysis until absence of chloride. The solid was obtained by centrifugation, dried at $70{ }^{\circ} \mathrm{C}$ and calcined at $500{ }^{\circ} \mathrm{C}$ as the chromium intercalated clays.

For the preparation of the intercalating solutions containing the two elements, the required amounts of $\mathrm{AlCl}_{3} \cdot 6 \mathrm{H}_{2} \mathrm{O}$ and $\mathrm{CrCl}_{3} \cdot 6 \mathrm{H}_{2} \mathrm{O}$ were dissolved in water at three $\mathrm{Al} / \mathrm{Cr}$ mole ratios, specifically $0.9: 0.1 ; 0.5: 0.5$ and 0.2:0.8. The three solutions were hydrolysed with a $\mathrm{NaOH}$ solution having a concentration of $1 \mathrm{~mol} / \mathrm{dm}^{3}$ at $\left(\mathrm{OH}^{-} / \mathrm{Al}^{3+}+\mathrm{Cr}^{3+}\right)$ mole ratios of 2.2, 2.1 and 2.0 , respectively. The rest of the preparation procedure was similar to the ones already described for the pillared clays containing only one metal [19].

The alumina-pillared solid, which may be considered as reference pillared clay, was used as the support for the preparation of the supported catalysts by incipient wetness impregnation. The salts used for the impregnation were ammonium chromate $\left(\mathrm{NH}_{4}\right)_{2} \mathrm{CrO}_{4}$ (Aldrich $98 \%$ ), chromium(II) acetate monohydrate dimer $\left[\mathrm{Cr}\left(\mathrm{CH}_{3} \mathrm{COO}\right)_{2} \cdot \mathrm{H}_{2} \mathrm{O}\right]_{2}$ (Aldrich) and chromium(III) nitrate nonahydrate $\mathrm{Cr}\left(\mathrm{NO}_{3}\right)_{3} \cdot 9 \mathrm{H}_{2} \mathrm{O}$, (Aldrich 99\%), which are precursors containing chromium in various oxidation states, that were dissolved in the minimum amount of water, in acetone in the case of the acetate, not soluble in water, and then added to the support. The resulting solids were dried and calcined in the same way as the pillared solids. In all cases, the final loading of the catalysts was 8 wt. $\%$ of $\mathrm{Cr}_{2} \mathrm{O}_{3}$.

Table 1

Chemical analyses (wt.\%) of the natural, pillared and impregnated solids, referred to dry solids (0\% water)

\begin{tabular}{|c|c|c|c|c|c|c|c|c|c|c|}
\hline Sample & $\mathrm{SiO}_{2}$ & $\mathrm{Al}_{2} \mathrm{O}_{3}$ & $\mathrm{Fe}_{2} \mathrm{O}_{3}$ & $\mathrm{MnO}$ & $\mathrm{MgO}$ & $\mathrm{CaO}$ & $\mathrm{Na}_{2} \mathrm{O}$ & $\mathrm{K}_{2} \mathrm{O}$ & $\mathrm{TiO}_{2}$ & $\overline{\mathrm{Cr}_{2} \mathrm{O}_{3}}$ \\
\hline Saponite & 60.09 & 5.77 & 1.65 & 0.03 & 30.70 & 0.71 & 0.27 & 0.52 & 0.25 & 0.00 \\
\hline $\mathrm{Al}_{1.0}$ & 56.46 & 14.56 & 1.51 & 0.03 & 26.64 & 0.11 & 0.04 & 0.44 & 0.22 & 0.00 \\
\hline $\mathrm{Al}_{0.9} \mathrm{Cr}_{0.1}$ & 54.35 & 15.19 & 1.46 & 0.03 & 25.73 & 0.05 & 0.05 & 0.37 & 0.22 & 2.55 \\
\hline $\mathrm{Al}_{0.5} \mathrm{Cr}_{0.5}$ & 52.40 & 10.66 & 1.41 & 0.03 & 24.20 & 0.04 & 0.04 & 0.44 & 0.22 & 10.55 \\
\hline $\mathrm{Al}_{0.2} \mathrm{Cr}_{0.8}$ & 51.37 & 7.83 & 1.38 & 0.03 & 23.81 & 0.04 & 0.02 & 0.36 & 0.20 & 14.96 \\
\hline $\mathrm{Cr}_{1.0}$ & 49.90 & 5.08 & 1.42 & 0.03 & 22.14 & 0.04 & 0.01 & 0.41 & 0.22 & 20.75 \\
\hline $\mathrm{Cr}_{\mathrm{ac}}$ & 51.67 & 13.58 & 1.45 & 0.03 & 24.19 & 0.10 & 0.02 & 0.33 & 0.22 & 8.39 \\
\hline Chromate & 51.99 & 13.36 & 1.40 & 0.03 & 24.34 & 0.09 & 0.01 & 0.35 & 0.21 & 8.22 \\
\hline $\mathrm{Cr}_{\mathrm{Nit}}$ & 51.90 & 13.57 & 1.41 & 0.03 & 24.49 & 0.10 & 0.04 & 0.42 & 0.22 & 7.82 \\
\hline
\end{tabular}


The intercalated-pillared solids are hereafter referred as $\mathrm{Al}_{x} \mathrm{Cr}_{y}$, with $x$ and $y$ being the mole fraction of $\mathrm{Al}$ and $\mathrm{Cr}$, respectively. The clay-based solids are referred by the name of the precursor used for impregnation, namely $\mathrm{Cr}_{\mathrm{ac}}$, Chromate and $\mathrm{Cr}_{\mathrm{Nit}}$ stand for the catalysts prepared starting from $\mathrm{Cr}$ (II) acetate, ammonium chromate and $\mathrm{Cr}(\mathrm{III})$ nitrate, respectively. In all cases, these references correspond to the dried samples; the suffix " $-500 "$ is added to designate the calcined solids.

\subsection{Characterization techniques}

X-ray diffraction (XRD) patterns of the solids were obtained over non-oriented powder samples, at a $2 \theta$ range from 2 to $65^{\circ}$, scanned at $2 \% \mathrm{~min}$. The instrument used was a Siemens D-500 diffractometer with filtered $\mathrm{Cu} \mathrm{K} \alpha$ radiation operated at $40 \mathrm{kV}$ and $30 \mathrm{~mA}$.

Elemental analysis of the solids was carried out by inductively coupled plasma optical emission spectroscopy (ICP OES) at Activation Laboratories Ltd., Ancaster, Ontario, Canada.

Specific surface area and pore size distributions were obtained by static adsorption of nitrogen (Air Liquide, $99.9992 \%$ ) at $-196{ }^{\circ} \mathrm{C}$, using a static volumetric apparatus (Micromeritics ASAP 2010 adsorption analyser). About $0.1 \mathrm{~g}$ of sample was used for each experiment, previously outgassed at a pressure lower than $6.67 \mathrm{~Pa}$, first at room temperature for $6 \mathrm{~h}$ and then at $110{ }^{\circ} \mathrm{C}$ for $2 \mathrm{~h}$.

Thermal studies were performed on Perkin-Elmer analysers, TGA7 and DTA7 for thermogravimetric and differential thermal analysis, respectively. All measurements were carried out at a heating rate of $10{ }^{\circ} \mathrm{C} / \mathrm{min}$ under a flow of $20 \mathrm{~cm}^{3} / \mathrm{min}$ of air (Air Liquide, 99.999\%) or nitrogen (Air Liquide, 99.9992\%).

FT-IR spectra were recorded in the $350-4000 \mathrm{~cm}^{-1}$ region on a Perkin-Elmer 1730 Infrared Fourier Transform Spectrometer. About $1 \mathrm{mg}$ of sample and $300 \mathrm{mg}$ of $\mathrm{KBr}$ (Panreac, for IR spectroscopy) were used in the preparation of the pellets.

DR-UV-vis spectra were recorded in reflectance mode on a Cary 5 spectrometer, with an optical length of $0.2 \mathrm{~cm}$.

Temperature-programmed reduction (TPR) analyses were carried out on a Micromeritics TPR/TPD 2900 instrument. About $40 \mathrm{mg}$ of sample were heated from room temperature to $900{ }^{\circ} \mathrm{C}$ at $10{ }^{\circ} \mathrm{C} / \mathrm{min}$, under a flow of $60 \mathrm{~cm}^{3} / \mathrm{min}$ of carrier gas $\left(5 \% \mathrm{H}_{2}\right.$ in Ar, Air Liquide). Hydrogen consumption was measured by a thermal conductivity detector (TCD) and $\mathrm{CuO}$ (Merck, 99.99\%) was used as an external standard for area calibration. Water and other compounds that may be formed during the precursor decomposition and the metal reduction were retained in a cold trap to avoid any interference with the measured signal.

The electron paramagnetic resonance (EPR) spectra were recorded at $-196{ }^{\circ} \mathrm{C}$ in a Bruker ER 200D spectrometer calibrated with DPPH (diphenyl picryl hydrazide). The samples were previously outgassed under vacuum conditions, ca. $26.6 \times 10^{-3} \mathrm{~Pa}$, for $1.5 \mathrm{~h}$.

Catalytic tests were carried out in a fixed bed flow reactor. The catalysts were sieved and the fraction between 125 and $250 \mu \mathrm{m}$ was used in the catalytic experiments. The feed was adjusted in order to evaluate the oxidant capacity of several reaction mixtures, choosing respectively oxygen and nitrogen oxides as oxidant agents. The propene concentration was attuned to $0.1 \% \mathrm{C}_{3} \mathrm{H}_{6}\left(1.86 \% \mathrm{C}_{3} \mathrm{H}_{6}\right.$ in $\mathrm{Ar}$, Air Liquide) mixing with $0.45 \% \mathrm{O}_{2}\left(20 \% \mathrm{O}_{2}\right.$ in $\mathrm{N}_{2}$, Air Liquide) or $0.9 \%$ $\mathrm{NO}_{x}\left(98 \% \mathrm{NO}+1 \% \mathrm{NO}_{2}+0.5 \mathrm{~N}_{2} \mathrm{O}\right.$, Carburos Metálicos) in argon (99.999\%, Air Liquide), establishing a total flow of $200 \mathrm{~cm}^{3} / \mathrm{min}$. The gas-hourly space velocity (GHSV) was fixed to $19000 \mathrm{~h}^{-1}$ after checking the optimum conditions to compare the catalysts. Propene oxidation was studied from 200 to $500{ }^{\circ} \mathrm{C}$, at intervals of $50{ }^{\circ} \mathrm{C}$. In all cases, the samples were raised to the measurement temperature with a temperature rate of $5{ }^{\circ} \mathrm{C} / \mathrm{min}$ and stabilized for $45 \mathrm{~min}$ prior to analysis, in order to ensure steady-state conditions. The reactants and products of the reaction were analysed by online infrared spectroscopy with a Perkin-Elmer 1725X FTIR spectrometer with a multiple reflection transmission cell (Infrared Analysis Inc.).

\section{Results and discussion}

\subsection{Characterization of the catalysts}

The solid intercalated with aluminium shows the X-ray diffractogram typical from alumina-pillared clays, see Fig. 1, sample $\mathrm{Al}_{1.0}$. The basal spacing increases from $13.81 \AA$, in the natural clay (diffractogram not shown), to $18.33 \AA$ in the intercalated solid. Also intercalation with aluminium-chromium polycations produces a shift of the basal $\left(\begin{array}{lll}0 & 0 & 1\end{array}\right)$ reflection peak to lower angles, indicating an increase in the basal spacing, intercalation being effective in all the solids considered, see Fig. 1. More differences are observed for the solids calcined at $500{ }^{\circ} \mathrm{C}$, although all of them show a layered structure, solids where aluminium is the only or the majority element are wellordered, while for solids where chromium is the only or the majority element, their ordering in the c-dimension is rather low. Literature data show that alumina-pillared clays are thermally stable, particularly alumina-pillared saponites, for which maintenance of the layered structure has been reported under calcination up to $700{ }^{\circ} \mathrm{C}$ [34]. However, chromia-pillared clays are thermally stable only up to $200{ }^{\circ} \mathrm{C}$ [19]. Thus, for aluminachromia-pillared clays, it is expected that alumina gives thermal stability to the solids, while increasing amounts of chromia will loss this stability. In XRD patterns, this effect may be observed as a total disappearance of $d_{00}{ }_{1}$ reflection peak, or at least as a strong decrease in its intensity, showing relative ordering due to the regions where the layered structure may be maintained by alumina pillars. This is the trend actually found; the solid $\mathrm{Al}_{1.0}-500$ shows an intense $d_{0}{ }_{0}{ }_{1}$ reflection at $18.48 \AA$, while the solid $\mathrm{Al}_{0.9} \mathrm{Cr}_{0.1}$ displays this reflection, also as an intense peak, at $17.21 \AA$ A. In opposite, the solid $\mathrm{Cr}_{1.0^{-}} 500$ shows a wide band between 10.05 and $12.92 \AA$. In the series where $\mathrm{Cr}$ is majority, $\mathrm{Cr}_{2} \mathrm{O}_{3}$-eskolaite peaks are detected in the solids calcined at $500{ }^{\circ} \mathrm{C}$.

As indicated before, the impregnated solids are prepared by using the saponite pillared with $\mathrm{Al}_{13}$ polycations, sample $\mathrm{Al}_{1.0}-500$, as support. The clay based solids maintain, in all 


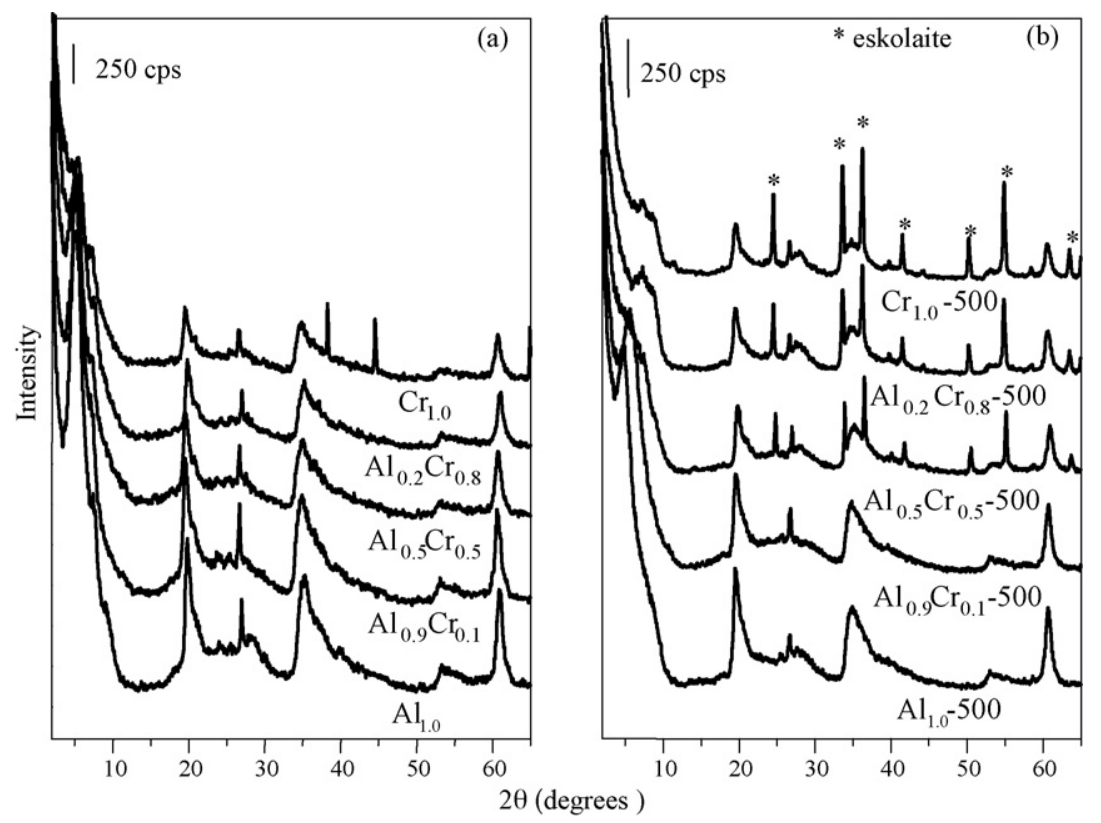

Fig. 1. XRD patterns of (a) intercalated and (b) pillared clays.

cases, the layered structure of the support, see Fig. 2, although with a loss in the ordering in the $c$-axis. When considering the diffractograms of the solids after calcination, which are the final catalysts, $c$-axis ordering is low, solids being mainly delaminated. No peaks of chromium oxides neither oxihydroxides are detected, this suggesting a high dispersion of the chromium species on the surface of the support, forming amorphous species or particles with size below the detection limit of X-ray diffraction, which is particularly interesting considering the relatively high amount of chromium used for impregnation.

The chemical analysis of the pillared solids reflects the fixation of aluminium and chromium during the intercalation process, together with the evolution of other elements of the clay. The chemical composition of all the solids are given in Table 1, for better comparison expressed as water-free composition calculated considering the sum of the metallic oxides as $100 \%$. A strong decrease in the amount of $\mathrm{Ca}$ and $\mathrm{Na}$ in the natural clay may be noticed, confirming that the incorporation of aluminium and chromium is produced by a cation exchange reaction between the polymeric cationic species of these elements in solution and the exchangeable cations in the interlayer region of saponite. The amount of aluminium and chromium fixed varies almost linearly with the molar ratio of the two elements in the intercalating solutions, reaching high fixation amounts, mainly in the case of

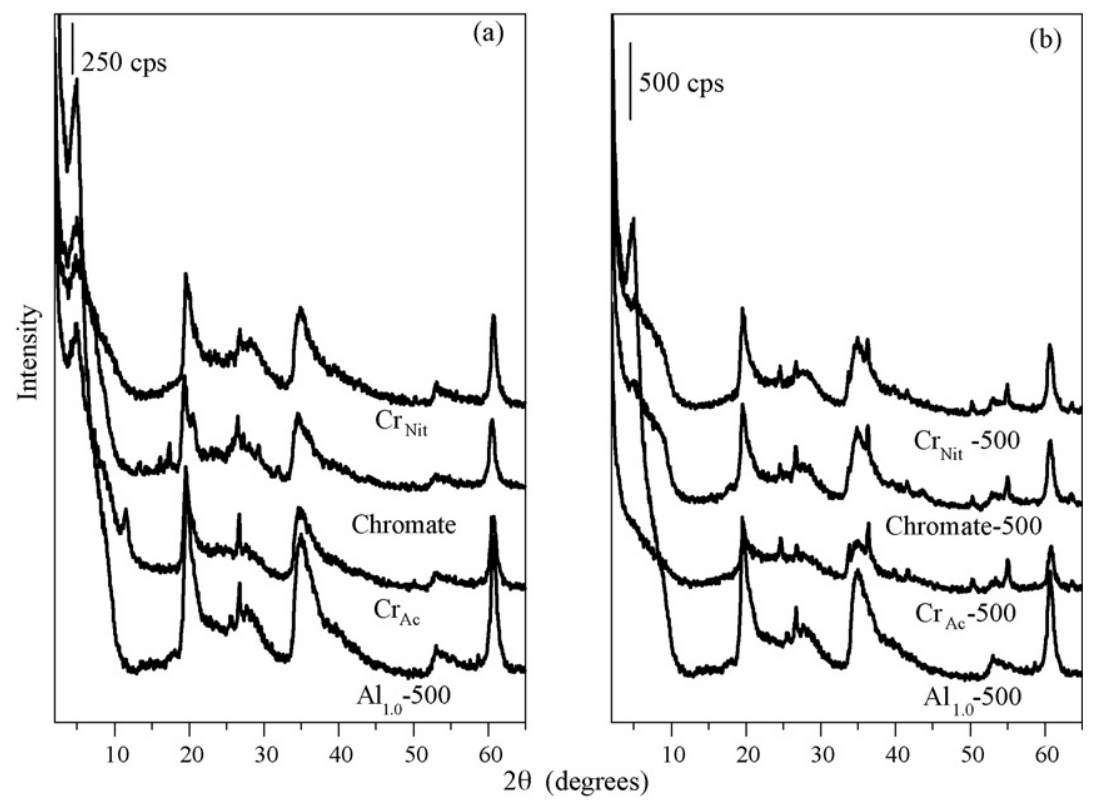

Fig. 2. XRD patterns of impregnated clays (a) before and (b) after calcination. 
Table 2

Effect of the chemical treatments on the composition of the pillared solids

\begin{tabular}{|c|c|c|c|c|c|c|c|c|c|c|}
\hline Sample & $\mathrm{SiO}_{2}$ & $\mathrm{Al}_{2} \mathrm{O}_{3}$ & $\mathrm{Fe}_{2} \mathrm{O}_{3}$ & $\mathrm{MnO}$ & $\mathrm{MgO}$ & $\mathrm{CaO}$ & $\mathrm{Na}_{2} \mathrm{O}$ & $\mathrm{K}_{2} \mathrm{O}$ & $\mathrm{TiO}_{2}$ & $\mathrm{Cr}_{2} \mathrm{O}_{3}$ \\
\hline Saponite & 60.09 & 5.77 & 1.65 & 0.03 & 30.70 & 0.71 & 0.27 & 0.52 & 0.25 & 0.00 \\
\hline $\mathrm{Al}_{1.0}$ & 60.09 & 15.50 & 1.61 & 0.03 & 28.35 & 0.12 & 0.04 & 0.47 & 0.24 & 0.00 \\
\hline $\mathrm{Al}_{0.9} \mathrm{Cr}_{0.1}$ & 60.09 & 16.80 & 1.61 & 0.03 & 28.45 & 0.05 & 0.05 & 0.41 & 0.25 & 2.81 \\
\hline $\mathrm{Al}_{0.5} \mathrm{Cr}_{0.5}$ & 60.09 & 12.23 & 1.62 & 0.03 & 27.76 & 0.04 & 0.04 & 0.51 & 0.25 & 12.10 \\
\hline $\mathrm{Al}_{0.2} \mathrm{Cr}_{0.8}$ & 60.09 & 9.16 & 1.61 & 0.03 & 27.86 & 0.04 & 0.03 & 0.42 & 0.24 & 17.50 \\
\hline $\mathrm{Cr}_{1.0}$ & 60.09 & 6.12 & 1.71 & 0.03 & 26.66 & 0.05 & 0.02 & 0.50 & 0.27 & 24.99 \\
\hline
\end{tabular}

Composition of pillared solids is referred to the $\mathrm{SiO}_{2}$ content in the natural saponite. All compositions given in wt.\% and referred to dry solids $(0 \%$ water).

chromium. Variations are also observed in the amount of other elements, in some cases, these are only relative variations due to the high amounts of aluminium and chromium incorporated to the solids. In order to better compare these variations, all compositions are referred in Table 2 to a reference value, the amount of $\mathrm{SiO}_{2}$ in the natural saponite, $60.09 \%$, being selected, because silicium is not altered in the treatments here carried out. When compositions are compared in this basis, it can be observed that the amount of $\mathrm{Al}_{2} \mathrm{O}_{3}$ fixed varies between 3 and $11 \%$, while the amount of $\mathrm{Cr}_{2} \mathrm{O}_{3}$ fixed varies between 3 and $25 \%$. The amount of aluminium incorporated in the $\mathrm{Al}_{1.0}$ solid is in good accordance with the amount expected for compensating the CEC of the clay, assuming that this element is majority forming $\mathrm{Al}_{13}{ }^{7+}$ units $[35,36]$. However, in the case of chromium, the amount fixed by the intercalated solids is clearly higher than that necessary for compensating CEC considering the polycationic species that this element can form. It may thus be proposed that chromium forms other polymeric species, or that a certain amount of this element is fixed in the surface of the clay. It is clearly observed in the normalized composition that the content of $\mathrm{Mg}$ decreases in the intercalated solids. The high sensibility of saponite clay under acidic conditions is well known, being $\mathrm{Mg}(\mathrm{II})$ in its octahedral positions easily leached $[37,38]$. It may be taken into account that the $\mathrm{pH}$ of the intercalating solutions is close to 4 , and although their leaching effect on the clay may be attenuated because of the slightly alkaline character of the clay suspension, it provokes an important dissolution of octahedral $\mathrm{Mg}$, almost $25 \%$ of the total amount of this element in the most acidic sample $\left(\mathrm{Cr}_{1.0}\right)$, with the subsequent deleterious effect in the layered ordering of the clays.

The formation of one or other of the polycations of chromium cited above strongly depends on the $\mathrm{Al} / \mathrm{Cr}$ ratio. As it has been previously reported by our own group [19], the cohydrolysis of both elements takes place with a competition for the hydroxyl groups added to the cation solutions. $\mathrm{Al}^{3+}$, because of its higher acidity, polymerises first, and thus $\mathrm{Cr}^{3+}$ polymerisation strongly depends on the limited amount of hydroxyl not employed for polymerisation of $\mathrm{Al}^{3+}$. This, together with the amount of hydroxyl added, between 2.0 and 2.2 of $\mathrm{OH} /$ metal mole ratios, makes that higher is the ratio of $\mathrm{Al}^{3+}$ in the solution, lower is the amount of hydroxyl available for $\mathrm{Cr}^{3+}$ polymerisation and consequently, lower the degree of polymerisation of this cation. This degree of polymerisation can be easily followed by visible spectroscopy, by study of the position and relative intensity of the two bands appearing between 400 and $600 \mathrm{~nm}$ [8-13]. Under the conditions used in this study, the trimeric species predominates in the solutions with stoichiometry $\mathrm{Cr}_{1.0}$ and $\mathrm{Al}_{0.2} \mathrm{Cr}_{0.8}$, the dimer predominates in the solution with stoichiometry $\mathrm{Al}_{0.5} \mathrm{Cr}_{0.5}$, and the monomer in the solution $\mathrm{Al}_{0.9} \mathrm{Cr}_{0.1}$. The presence of these species in the intercalating solutions is compatible with the basal spacing observed by X-ray diffraction, when comparing the interlayer distance with the height of the polycations calculated by Volzone [33].

The chemical composition given in Table 1 shows that the impregnated solids have $\mathrm{Cr}_{2} \mathrm{O}_{3}$ contents close to $8 \mathrm{wt}$.\%, the content targeted during the synthesis. The differences with respect to this value are due to the degree of hydration of the solids in each step of the synthesis.

The nitrogen adsorption-desorption isotherms of the solids are shown in Figs. 3 and 4. As can be observed, a high amount of nitrogen is adsorbed at low relative pressure. All the isotherms are of type I + II from the IUPAC classification, with a hysteresis loop type $\mathrm{H} 3$, behaviour characteristic of layered materials with slit-like pores $[39,40]$. The structural parameters calculated from these isotherms are given in Table 3. Specific surface areas were obtained by the BET method, the external surface area by the $t$-method, the total pore volume was calculated from the amount of nitrogen adsorbed at a relative pressure of 0.99 , and the micropore size distributions by using the Horvath-Kawazoe method [41].

First of all, it may be noticed that the specific surface area of the natural saponite is rather high, clearly higher than the values usually reported for natural smectites in general, and for saponites in particular $\left(30-50 \mathrm{~m}^{2} / \mathrm{g}\right)$. However, high BET surface area values have been reported by several authors for saponites in Madrid Basin, which has been attributed to the very small particle size of these clays due to their sedimentary origin $[37,38,42]$. Surface area shows the higher values for the solids intercalated with solutions containing only one cation, $\mathrm{Al}^{3+}$ or $\mathrm{Cr}^{3+}$, while solids derived from mixed solutions show lower values, although the decrease is only remarkable for $\mathrm{Al}_{0.9} \mathrm{Cr}_{0.1}$ solid.

Thermal treatment at $500{ }^{\circ} \mathrm{C}$ affects the solids depending on their composition. Thus, solids $\mathrm{Al}_{1.0}-500, \mathrm{Al}_{0.9} \mathrm{Cr}_{0.1}-500$ and even $\mathrm{Al}_{0.5} \mathrm{Cr}_{0.5}-500$ maintain a high percentage of the surface area of the corresponding counterparts before calcination, between 81 and $93 \%$. A loss of 42 and $37 \%$ of the surface area of the intercalated solids is observed in the samples $\mathrm{Al}_{0.2} \mathrm{Cr}_{0.8}$ and $\mathrm{Cr}_{1.0}$, respectively. This is related, to a large extent, to the thermal stability of the solids under calcination, as previously 


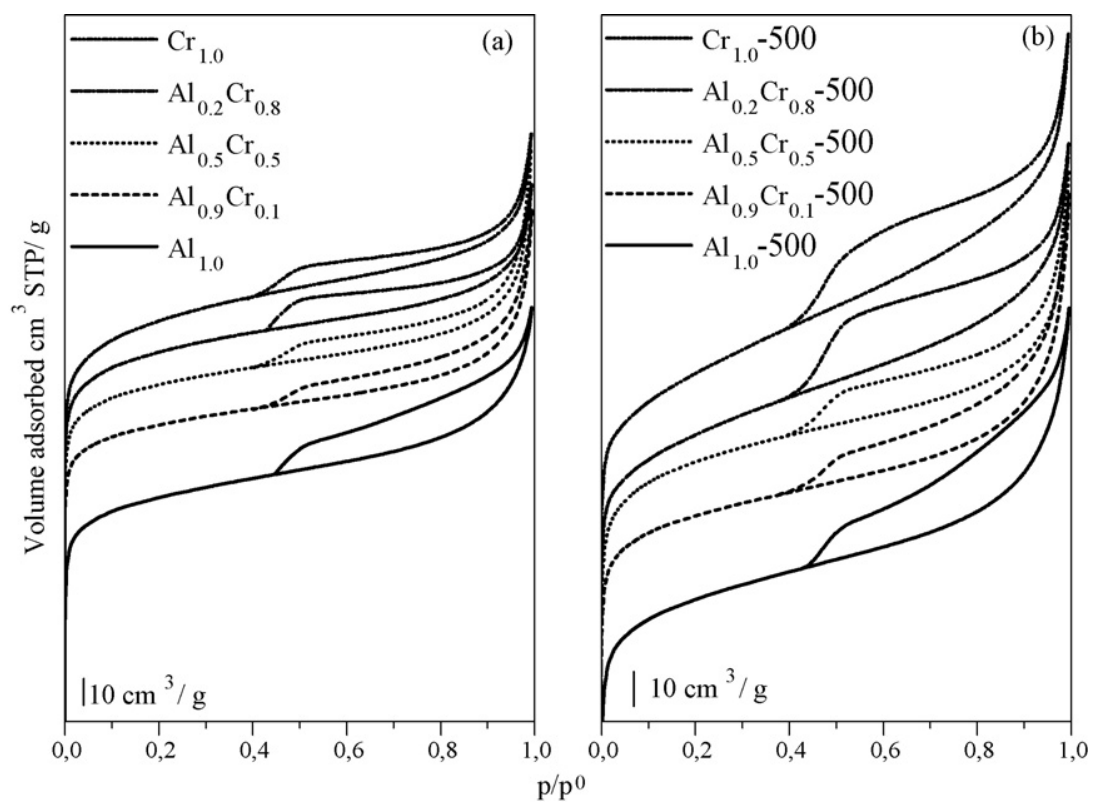

Fig. 3. Nitrogen adsorption-desorption isotherms at $-196{ }^{\circ} \mathrm{C}$ of (a) intercalated and (b) pillared clays.

discussed when reporting their XRD data, the high collapse of chromium-rich solids under calcination at $500{ }^{\circ} \mathrm{C}$ entails a strong loss in surface area, while the maintenance of an ordered layered structure in the aluminium-rich solids causes the maintenance of most of surface area. Surface area always losses because calcination at $500{ }^{\circ} \mathrm{C}$ entails the removal of water from the polycationic species, thus provoking a decrease in the length of pillaring unities, or even the collapse of the layered structure observed by X-ray diffraction. The microporous surface contributes in a very significant way to the total surface area of the solids, reaching values between 84 and $87 \%$ in the intercalated solids and between 56 and $82 \%$ in the pillared counterparts.
The specific surface area of the materials leads very different results for the dried and the calcined impregnated solids. The solids dried at $70{ }^{\circ} \mathrm{C}$ show strong decreases of surface area with respect to the support, showing values as low as $6 \mathrm{~m}^{2} / \mathrm{g}$, even lower than the external surface area of the clay particles, meaning that the chromium salt has not only occluded the intraparticular porosity, but is acting as a kind of glue sticking the particles together. When the solids are calcined at $500{ }^{\circ} \mathrm{C}$ the surface area increases. The incorporation of the precursors, in some cases containing big organic moieties, strongly blocks the access to the interlayer microporous region of the support, causing the commented decrease in the surface area. The calcination of the solids to form the final catalysts causes the
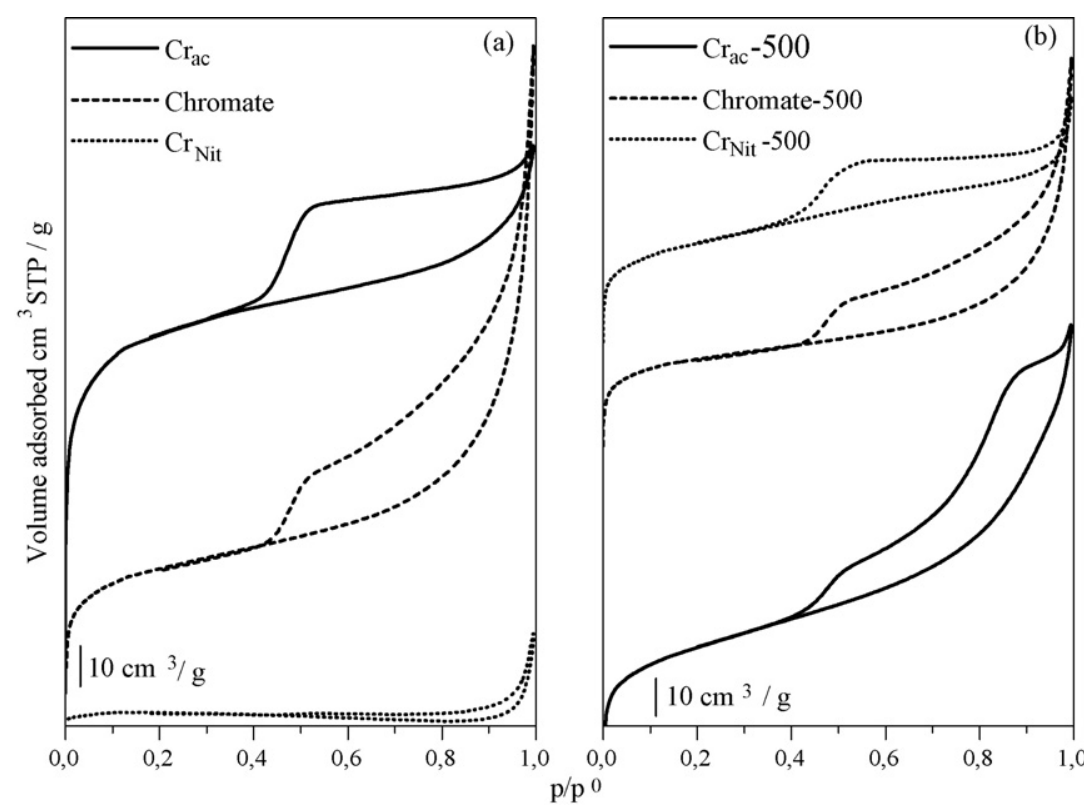

Fig. 4. Nitrogen adsorption-desorption isotherms at $-196{ }^{\circ} \mathrm{C}$ of the impregnated clays: (a) before and (b) after calcination. 
Table 3

BET surface area $\left(S_{\mathrm{BET}}\right)$, micropore surface area $\left(S_{\mu \mathrm{p}}\right)$, total pore volume $(\mathrm{Vp})$, and micropore diameter of the solids

\begin{tabular}{|c|c|c|c|c|c|c|c|c|}
\hline \multirow[t]{2}{*}{ Sample } & \multicolumn{2}{|c|}{$S_{\mathrm{BET}}\left(\mathrm{m}^{2} / \mathrm{g}\right)$} & \multicolumn{2}{|c|}{$S_{\mu \mathrm{p}}\left(\mathrm{m}^{2} / \mathrm{g}\right)$} & \multicolumn{2}{|c|}{$V_{\mathrm{p}}\left(\mathrm{cm}^{3} / \mathrm{g}\right)$} & \multicolumn{2}{|c|}{ Micropore diameter $(\AA)$} \\
\hline & $110^{\circ} \mathrm{C}$ & $500{ }^{\circ} \mathrm{C}$ & $110^{\circ} \mathrm{C}$ & $500{ }^{\circ} \mathrm{C}$ & $110^{\circ} \mathrm{C}$ & $500{ }^{\circ} \mathrm{C}$ & $110^{\circ} \mathrm{C}$ & $500{ }^{\circ} \mathrm{C}$ \\
\hline Saponite & 169 & & 111 & & 0.195 & & 5.5 & \\
\hline $\mathrm{Al}_{1.0}$ & 334 & 274 & 283 & 218 & 0.244 & 0.230 & 6.0 & 5.5 \\
\hline $\mathrm{Al}_{0.9} \mathrm{Cr}_{0.1}$ & 258 & 240 & 217 & 191 & 0.220 & 0.231 & 5.3 & 5.4 \\
\hline $\mathrm{Al}_{0.5} \mathrm{Cr}_{0.5}$ & 311 & 252 & 270 & 207 & 0.260 & 0.224 & 5.4 & 5.4 \\
\hline $\mathrm{Al}_{0.2} \mathrm{Cr}_{0.8}$ & 327 & 191 & 285 & 120 & 0.226 & 0.202 & 5.4 & $5.9-8.8$ \\
\hline $\mathrm{Cr}_{1.0}$ & 328 & 209 & 280 & 117 & 0.243 & 0.231 & 5.4 & $5.9-8.7$ \\
\hline $\mathrm{Cr}_{\mathrm{ac}}$ & 187 & 177 & 168 & 105 & 0.112 & 0.157 & 5.5 & 5.8 \\
\hline Chromate & 72 & 97 & 44 & 61 & 0.015 & 0.257 & 8.0 & $7.0-8.9$ \\
\hline $\mathrm{Cr}_{\mathrm{Nit}}$ & 6 & 107 & n.a. ${ }^{a}$ & 73 & 0.094 & 0.251 & n.a. & $6.5-9.4$ \\
\hline
\end{tabular}

${ }^{\text {a }}$ Not applicable.

removal of the precursor components, and consequently opening the access to the previously blocked internal porosity. At this respect, the thermal curves show the decomposition of the organic moieties of the precursors as very exothermal processes centred at about $380{ }^{\circ} \mathrm{C}$, and the FT-IR spectra of the final catalysts, calcined at $500{ }^{\circ} \mathrm{C}$, confirms the absence of organic matter in them. For the nitrate precursor, no evidence of bands related to nitrate species appears in the corresponding FT-IR spectra of the $\mathrm{Cr}_{\mathrm{Nit}}-500$ sample indicating the removal of the nitrate precursor component. In any case, because of the incorporation of chromium and the commented partial collapse of the layered support structure during the impregnationdrying-calcination processes, the surface area of the supported catalysts is always lower than that of the support.

The total pore volume, determined from the amount of nitrogen adsorbed at a relative pressure of 0.99 is rather high, reaching for some solids values higher than $0.20 \mathrm{~cm}^{3} / \mathrm{g}$, probably related to interparticular porosity. The micropore size distribution of the solids, Fig. 5, determined by the HorvathKawazoe method, show that most of the solids have a monomodal pore distribution, with a maximum centred at
5.3-6.0 А. Some of the solids calcined at $500{ }^{\circ} \mathrm{C}$ present a bimodal distribution, with maxima close to 5.9 and $9.4 \AA$. This bimodal distribution has been previously reported for pillared clays [43], and as observed is maintained by some of the impregnated solids now prepared.

The DR-UV-vis spectra of the solids show the characteristic bands of $\mathrm{Cr}$ (III) in octahedral environment, see Fig. 6. This cation shows three spin-allowed bands, usually two of them appearing in the visible region $\left(v_{1}\right.$ and $\left.v_{2}\right)$ and the other appearing overlapped by the strong charge transference in the UV region $\left(v_{3}\right)$, and also a spin-forbidden transition called the "ruby line" $\left(v_{4}\right)$. The spectra of the intercalated and pillared solids are very similar, with the visible bands centred at about 430 and $600 \mathrm{~nm}$ in the intercalated solids and at 460 and $600 \mathrm{~nm}$ for the pillared ones. The small shift observed in $v_{2}$ to high wavelength, that is, to low energy, for the pillared solids, and the subsequent decrease in the Racah parameters (not given) indicates that the pillared solids are more covalent that the intercalated ones, which accords with the dehydration and dehydroxilation that encompasses the calcination step carried out to transform the intercalated solids into the pillared ones, in

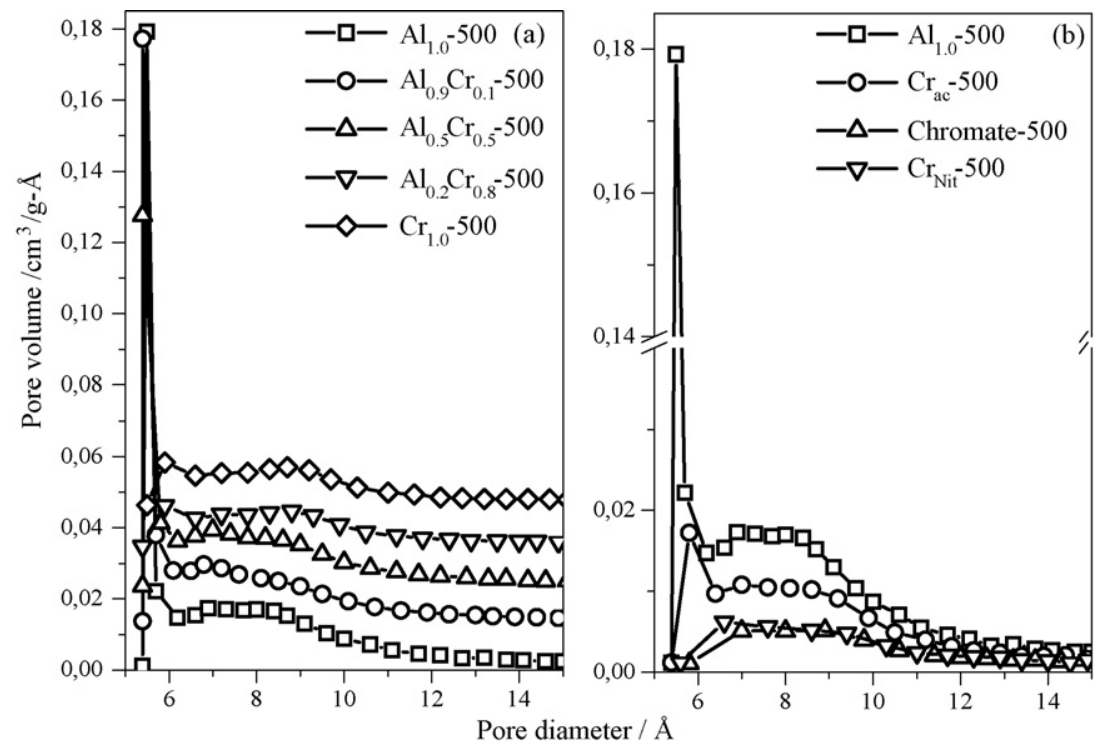

Fig. 5. Micropore size distribution for (a) pillared and (b) impregnated clays. 


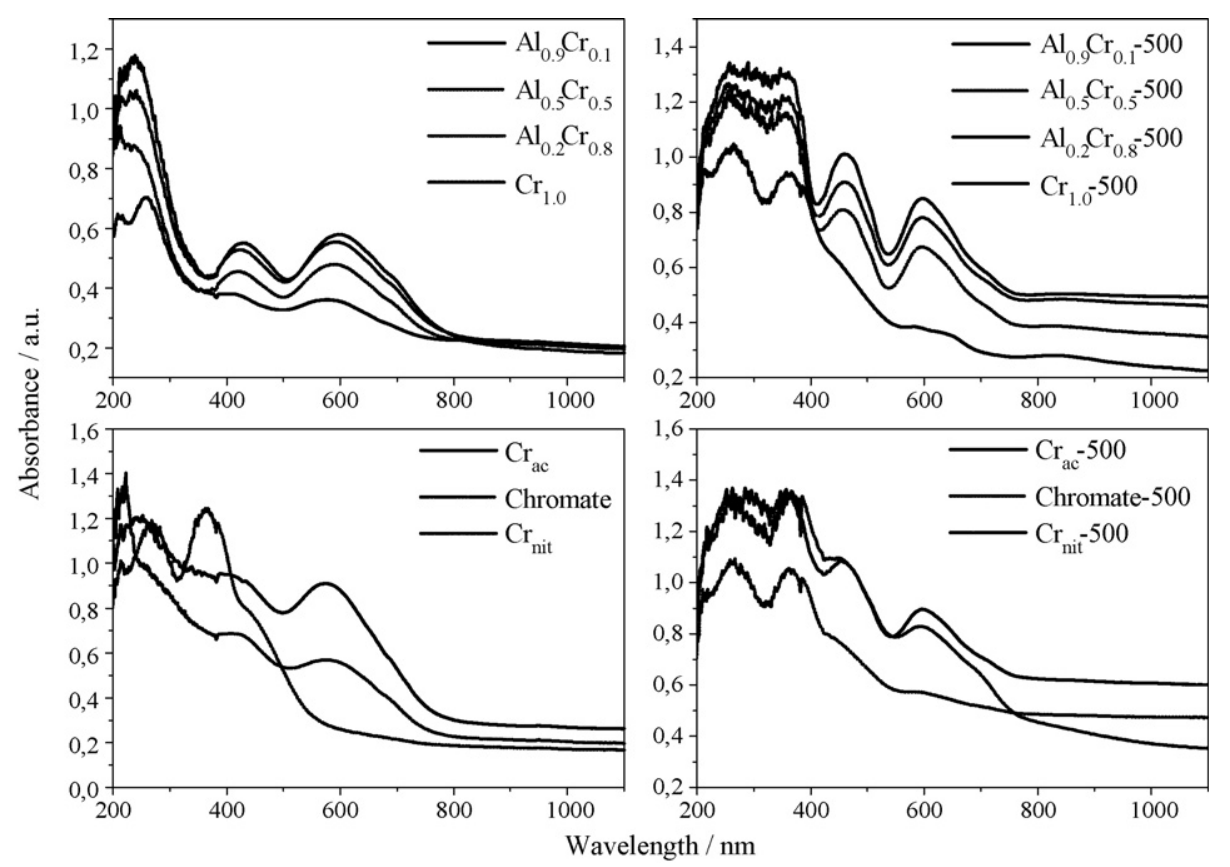

Fig. 6. DR-UV-vis spectra of intercalated-pillared and of impregnated clays.

other words, to transform the polycations into pillars [44]. As indicated, the impregnated solids show spectra rather different from the dried to the calcined solids, being remarkable that the spectra of the calcined solids are similar to those of the pillared solids, both series calcined at $500{ }^{\circ} \mathrm{C}$. No bands that may be due to oxidation states different from $\mathrm{Cr}$ (III) were observed, although it may be noticed that $\mathrm{Cr}(\mathrm{VI})$ species do not present d$\mathrm{d}$ transitions. Thus, having in mind the limitation commented about the fact that visible spectroscopy is blind to $\mathrm{Cr}(\mathrm{VI})$ species, it may be said that, independently of the precursor used in the impregnation the further treatments, particularly the calcination at $500{ }^{\circ} \mathrm{C}$, make all the final catalysts to contain similar chromium species.

Temperature-programmed reduction of the final catalysts shows that most of chromium in the solids is in the trivalent state. The reduction profiles, see Fig. 7, of natural saponite and of the $\mathrm{Al}_{1.0^{-}}-500$ solid present a small reduction effect at high temperature due to the small amount of $\mathrm{Fe}$ (III) in the octahedral positions of the saponite. Besides of this effect, the solids containing chromium present two reduction effects, the first one centred at $390-400{ }^{\circ} \mathrm{C}$ in the pillared solids and at $375-390{ }^{\circ} \mathrm{C}$ in the impregnated solids, and the second one appearing as a

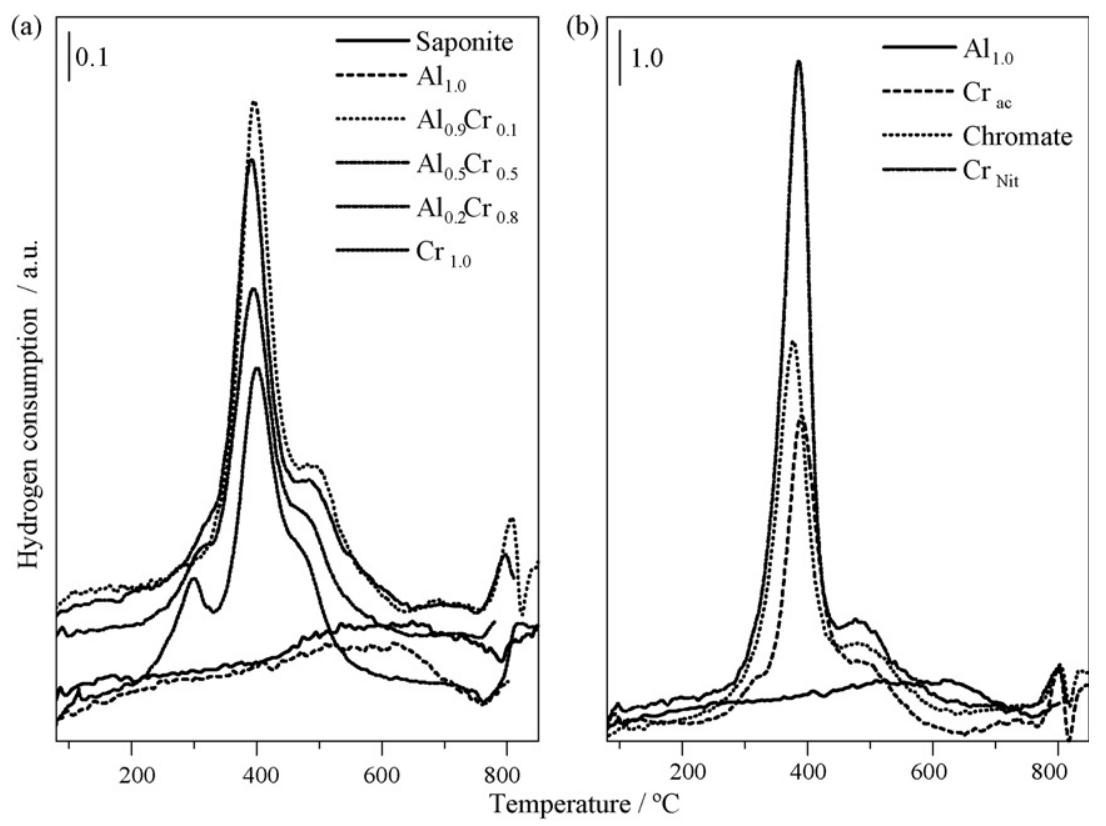

Fig. 7. TPR curves of (a) pillared and (b) impregnated clays. 
Table 4

Percentage of $\mathrm{Cr}(\mathrm{VI})$ related to the total content of $\mathrm{Cr}$ in the solids calcined at $500{ }^{\circ} \mathrm{C}$

\begin{tabular}{lc}
\hline Sample & $\mathrm{Cr}(\mathrm{VI})$ content $(\%)$ \\
\hline $\mathrm{Al}_{0.9} \mathrm{Cr}_{0.1}$ & 58.2 \\
$\mathrm{Al}_{0.5} \mathrm{Cr}_{0.5}$ & 14.3 \\
$\mathrm{Al}_{0.2} \mathrm{Cr}_{0.8}$ & 7.3 \\
$\mathrm{Cr}_{1.0}$ & 5.4 \\
$\mathrm{Cr}_{\mathrm{ac}}$ & 16.6 \\
$\mathrm{Chromate}$ & 21.4 \\
$\mathrm{Cr}_{\text {Nit }}$ & 34.4 \\
\hline
\end{tabular}

shoulder of the former, at $475^{\circ} \mathrm{C}$. It has been reported that the calcination of solids containing chromium under oxidant atmosphere produces $\mathrm{Cr}(\mathrm{VI})$ species at moderate temperature, which decompose at higher temperature giving $\mathrm{Cr}(\mathrm{III})$ species. The amount of $\mathrm{Cr}(\mathrm{VI})$ has been reported to be close to $100 \%$ in some solids after calcination at $400{ }^{\circ} \mathrm{C}$, but strongly decreasing when the calcination temperature increases to $500{ }^{\circ} \mathrm{C}$ [45]. Taking in consideration that our solids have been calcined at $500{ }^{\circ} \mathrm{C}$ in air, it is not reasonable to expect that chromium may be in the solids as $\mathrm{Cr}(\mathrm{II})$, and if it is as $\mathrm{Cr}(\mathrm{VI})$ it may be easily reduced up to $\mathrm{Cr}(\mathrm{III})$ by hydrogen, this reduction not continuing to $\mathrm{Cr}(\mathrm{II})$.

The TPR curves of the impregnated catalysts are similar to that of $\mathrm{CrO}_{3}$. This suggests that the $\mathrm{Cr}(\mathrm{VI})$ species present in the solids are close to $\mathrm{Cr}(\mathrm{VI})$ oxide, even when ammonium chromate was used as precursor. Assuming that the reduction effects are due to the process $\mathrm{Cr}(\mathrm{VI}) \rightarrow \mathrm{Cr}(\mathrm{III})$ and the absence of other reduction processes, they allow to calculate the amount of chromium present in the solids calcined at $500{ }^{\circ} \mathrm{C}$ as $\mathrm{Cr}(\mathrm{VI})$ species, data given in Table 4, or alternatively to calculate an average oxidation state for chromium [45,46]. It was found that between 5.4 and $58.2 \%$ of total chromium is under the form of $\mathrm{Cr}(\mathrm{VI})$ species. However, it may be considered that the value of $58.2 \%$ of $\mathrm{Cr}(\mathrm{VI})$ is found for solid $\mathrm{Al}_{0.9} \mathrm{Cr}_{0.1}-500$, and because of the low amount of $\mathrm{Cr}$ fixed by this solid (see Table 1), the determination of the amount of $\mathrm{Cr}(\mathrm{VI})$ in this solid from hydrogen consumption has a high relative error. In the pillared solids, when higher is the amount of chromium fixed during the intercalation, lower is the percentage of $\mathrm{Cr}(\mathrm{VI})$ after calcination. In the impregnated solids, although the amount of chromium is very similar in all of them, the percentage of $\mathrm{Cr}$ in the $\mathrm{Cr}(\mathrm{VI})$ form varies between 16.6 and $34.4 \%$, suggesting that the amount of $\mathrm{Cr}(\mathrm{VI})$ after calcination at $500{ }^{\circ} \mathrm{C}$ depends on the nature of the precursor used. The amount of chromium that remains in the $\mathrm{Cr}(\mathrm{VI})$ form after calcination at $500{ }^{\circ} \mathrm{C}$ is clearly higher than that reported for other solids, in which even all chromium is in the trivalent form after calcination at this temperature [45].

The characterization of chromium in the catalysts studied was completed by EPR measurements, which spectra are shown in Fig. 8. There are some reports describing the EPR investigations of chromium species on several oxide surfaces $[47,48]$. Mainly, three signals have been found in the EPR spectra of $\mathrm{Cr}$-catalysts denoted as $\gamma, \beta$ and $\delta$. The axial $\gamma$-signal is centred at a $g$-factor value of 1.9 and it has been assigned to

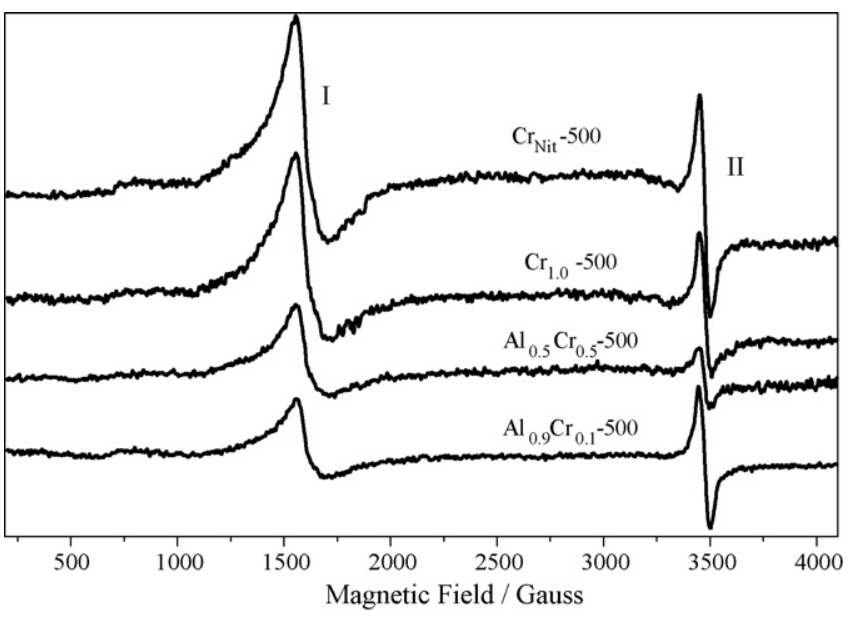

Fig. 8. EPR spectra of the samples indicated recorded at $-196^{\circ} \mathrm{C}$ after outgassing.

isolated $\operatorname{Cr}(\mathrm{V})$ species $[49,50]$. Whereas, the $\beta$-signal is attributed to $\mathrm{Cr}_{2} \mathrm{O}_{3}$-like clusters and the $\delta$-signal is associated to isolated or dispersed $\mathrm{Cr}(\mathrm{III})$ species [51]. Although again EPR can not detect $\mathrm{Cr}(\mathrm{VI})$ species and thus we can not infer results about species with this oxidation state from this technique, the presence and nature of these signals are dependent to the synthesis procedure, the support and the loading.

The EPR spectra of all catalysts studied present the same two signals, denoted as I and II. The signal I is centred at a $g$ of 4.2 with a shoulder located at a $g$ of 9 . It has an axial shape and it can be attributed to the presence of isolated octahedral $\mathrm{Fe}^{3+}$ species subjected to a rhombic distortion [52]. These iron species are located in the octahedral layer of the original clay, whose presence has been indicated previously in Table 1. Signal II is a symmetrical line centred at a $g$ of 1.97 whose assignation offers some controversy. Depending on the support, at this position could appear the line assigned to $\operatorname{Cr}(\mathrm{V})$, denoted $\gamma$ signal, but also could be assigned to the presence of $\mathrm{Cr}(\mathrm{III})$ as $\alpha-\mathrm{Cr}_{2} \mathrm{O}_{3}$, signal $\beta[47,51]$. It is also important to remark that the literature also proposed the hypothesis of a trimer of mixed valence $\left(\mathrm{Cr}^{6+}-\mathrm{Cr}^{3+}-\mathrm{Cr}^{6+}\right)$ with average oxidation state of 5 as $\gamma$-signal assignation [47]. In order to complete the EPR characterization, the same spectra were recorded at room temperature (not shown). The intensity of signal II decreased when the annealing temperature increased. This change is characteristic of the transformation of the paramagnetic species into non-paramagnetic species. This reduction in the intensity has been related to $\mathrm{Cr}_{2} \mathrm{O}_{3}$, which is weakly paramagnetic, being the dipolar interaction more notable than the interchange interaction at high temperatures [53]. In this sense, the characterization of chromium-saponite performed by various techniques confirms the presence of $\mathrm{Cr}(\mathrm{III})$ and $\mathrm{Cr}(\mathrm{VI})$ species in all the catalysts studied.

\subsection{Catalytic performance}

Selected solids were first tested for the catalytic reduction of NOx with propene, showing low activity for the nitrogen oxides reduction although high activity for the hydrocarbon oxidation, 

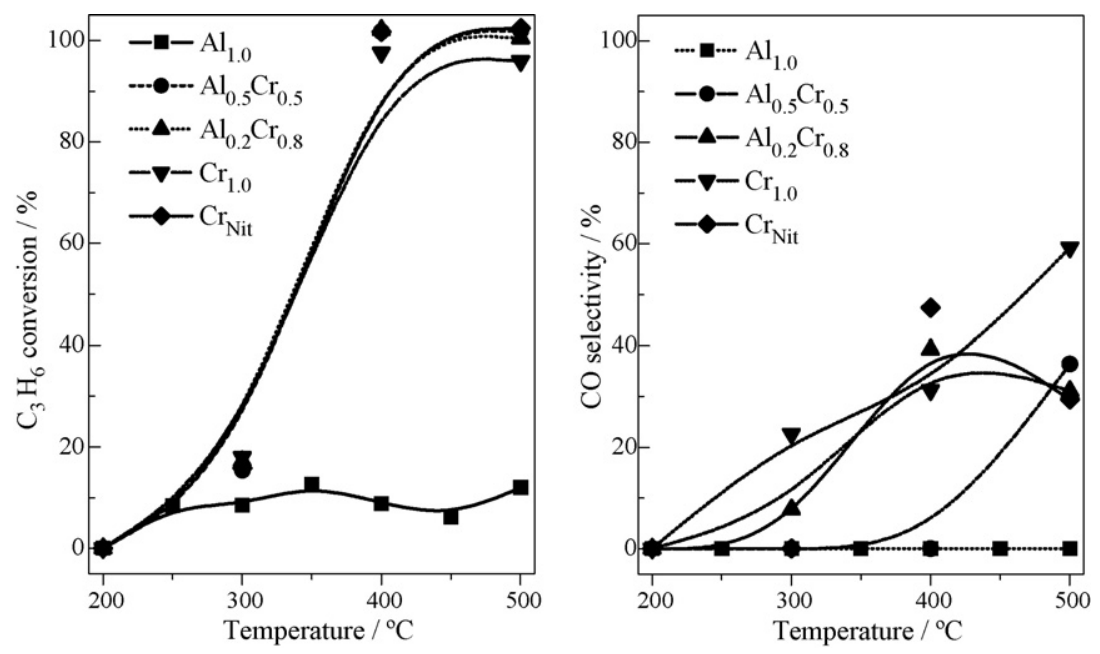

Fig. 9. Conversion of propene and selectivity to $\mathrm{CO}$ for propene oxidation.

thus, we focused our attention on their catalytic behaviour for oxidation of propene. However, some results obtained in the NOx reaction are useful for explaining the catalytic performance of the solids.

The results obtained for the oxidation of propene, in presence of oxygen, are shown in Fig. 9. The conversion of propene reaches values of $100 \%$ for all the catalysts studied at $400{ }^{\circ} \mathrm{C}$, independently of the amount of chromium incorporated to the clay in the pillaring or impregnation processes. The effect of chromium amount only is apparent at lower temperatures. At $300{ }^{\circ} \mathrm{C}$ the increase of chromium percent slightly improves the propene conversion. This behaviour suggests that low amounts of chromium are effective for the propene oxidation reaction. As reference, the support used for the preparation of the impregnated solids, aluminium-pillared sample $\left(\mathrm{Al}_{1.0^{-}} 500\right)$, was included in Fig. 9 in order to evaluate its influence in the catalytic behaviour. The catalytic performance of this sample is very low, even at high temperatures, indicating that the behaviour of the catalysts evaluated is mainly due to the chromium species incorporated to the pillared clay.

The pillared and the impregnated solids have the same behaviour, as shown in Fig. 9, indicating that the catalytic performance does not depend on the method in which chromium was incorporated. This element acts as the active phase in oxidation reactions both if it is mainly located in the interlayer region or on the external surface of the clay. The propene combustion is not complete, as it has been described in literature for other chromium combustion catalysts [23]. At $350{ }^{\circ} \mathrm{C}, \mathrm{CO}$ is detected together with $\mathrm{CO}_{2}$ as reaction products. The CO selectivity reached at $500{ }^{\circ} \mathrm{C}$ is $40 \%$ for all the samples studied, except for the $\mathrm{Cr}_{1.0}-500$ sample, which reached $60 \%$ CO selectivity, see Fig. 9.

The hydrocarbon oxidation begins at low temperatures, $250{ }^{\circ} \mathrm{C}$, in all the solids studied. The reaction is activated from 300 to $400{ }^{\circ} \mathrm{C}$, reaching the maximum at this last temperature. This temperature should be related with the reduction peak observed in the $\mathrm{H}_{2}$-TPR measurements described before, attributed to the $\mathrm{Cr}(\mathrm{VI}) \rightarrow \mathrm{Cr}(\mathrm{III})$ reduction. Thus, the activity of these materials could be attributed to the easy oxidation of
$\mathrm{Cr}^{3+}$ ions to $\mathrm{Cr}^{6+}$ on the surface of chromium oxides. Similar relation between the activity and the TPR results has been described in the literature based on metal oxide catalysts for hydrocarbon combustion [54]. The two oxidation states are present in the chromium catalysts studied, as it has been described before by TPR, EPR and UV-vis measurements. Chromium could present multiple oxidation states by an attachment to extra-lattice oxygen atoms. Due to its large atomic radius, the electron in its outermost shell (3d) is relatively easy to give high oxidation states and, thus, produce high redox potential. It is expected that the increase in oxidation state cause the increase of the electron accepting ability of chromium $[23,55]$. The high oxidation state is suitable to be reduced by organic compounds, giving low oxidation degrees capable to be oxidized by the oxygen, thus, closing the redox cycle.

When using NO as oxidant agent, the catalysts behaviour was considerably different to that observed when using oxygen as oxidant, shown in Fig. 10A. The oxidation of propene reached conversions close to $80 \%$ at high temperature, when pillared and impregnated catalysts are used. However, the conversion of NO reached values close to $30 \%$, that is, much lower than those reached for propene conversions. The yield to diatomic nitrogen under these conditions results analogous to $\mathrm{NO}_{x}$ conversions for all catalysts studied. As there are no other oxidant agents in the feed, these results suggest that the catalysts contribute to the oxidation of the hydrocarbon by means of a Mars-van Krevelen mechanism. Assuming the Mars-van Krevelen when using NO as oxidant, the high oxidation activity of the chromium-catalysts for propene oxidation can also be explained by the Mars-van Krevelen model $[56,57]$, described in literature as the most suitable to represent the VOC's combustion reaction [54,58].

Considering the behaviour observed when using oxygen or nitrogen oxide as oxidants, the reaction was carried out in the joint presence of both oxidants. The stoichiometric ratio propene-oxidants were maintained, making that the two oxidants give the same amount of oxygen atoms $\left(\mathrm{C}_{3} \mathrm{H}_{6}+4.5 \mathrm{NO}+2.25 \mathrm{O}_{2}\right)$. The conversion of propene found 

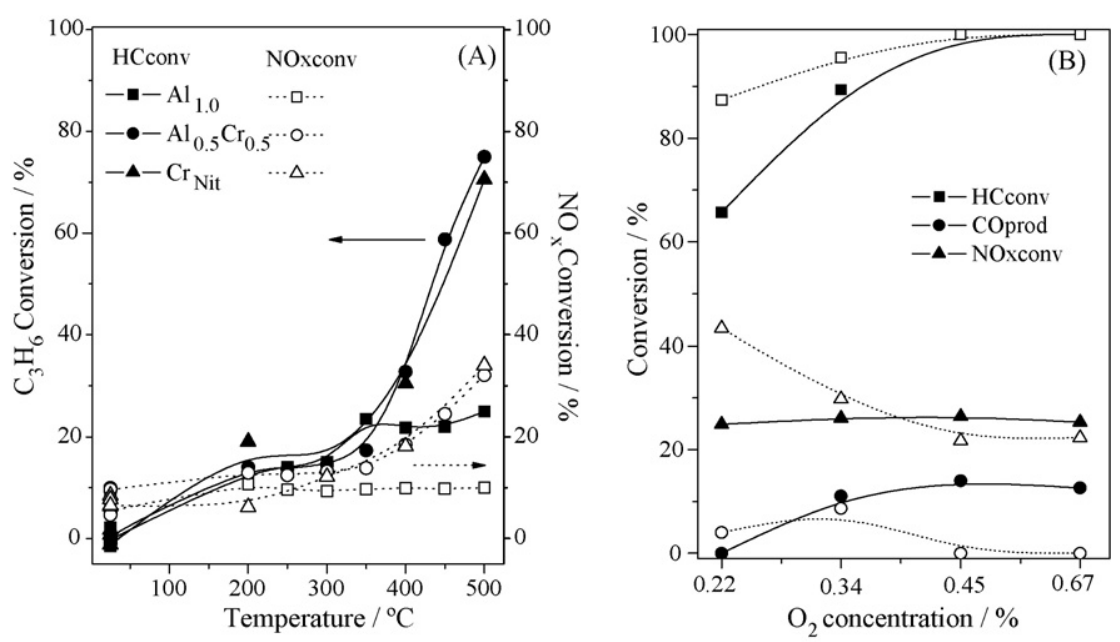

Fig. 10. Catalytic performance results with $\mathrm{NO}$ as oxidant: (A) $\mathrm{C}_{3} \mathrm{H}_{6}$ and $\mathrm{NO}_{x}$ conversions for the catalysts indicated, showing the $\mathrm{Al}_{1.0}$ as reference; (B) $\mathrm{C}_{3} \mathrm{H}_{6}, \mathrm{NO}_{x}$ conversions and $\mathrm{CO}$ production for the $\mathrm{Al}_{0.5} \mathrm{Cr}_{0.5}$ catalysts with increasing amounts of $\mathrm{O}_{2}$; (full lines, $400{ }^{\circ} \mathrm{C}$, dotted lines, $500{ }^{\circ} \mathrm{C}$ ).

under these conditions reached higher values than when using only NO. The reaction was favoured by the presence of oxygen (not shown). This behaviour was observed for all the clay-based catalysts, reaching conversions close to $80 \%$ for propene and to $40 \%$ for NO. The yield to nitrogen runs parallel to the conversion of NO, no other nitrogenous species were detected. In all catalysts studied, the oxidant contribution is able to produce the complete combustion of the hydrocarbon, without evidences of the presence of $\mathrm{CO}$, behaviour similar to that described for NO reaction.

The effect of the amount of oxygen in the oxidant mixture $\mathrm{NO}+\mathrm{O}_{2}$ was investigated by adding increasing amounts of oxygen under isothermal conditions, at 400 and $500{ }^{\circ} \mathrm{C}$. All the catalysts showed a similar behaviour, shown in Fig. 10B. At $400{ }^{\circ} \mathrm{C}$, when the conversion of propene has not reached $100 \%$, the addition of oxygen favoured the oxidation of the hydrocarbon without provoking a decrease in the reduction of the nitrogen oxides, even for high oxygen concentrations. This supposes the existence of a synergic effect between $\mathrm{O}_{2}$, $\mathrm{NO}$ and the $\mathrm{O}-\mathrm{Cr}$ species at this temperature. However, at $500{ }^{\circ} \mathrm{C}$, when the conversion of propene was already $100 \%$, the excess of oxygen competed with the nitrogen oxides for the oxidation of propene, the hydrocarbon reacted preferably with oxygen strongly decreasing the conversion of the nitrogen oxides. A modified Mars-van Krevelen model has been claimed in the literature for explaining the synergy between $\mathrm{O}_{2}$ and NO for total oxidation abatement of VOC's [58]. The authors proposed that firstly the $\mathrm{NO}$ would react with $\mathrm{O}_{2}$ at the catalyst surface to form $\mathrm{NO}_{2}$. Consequently, the $\mathrm{NO}_{2}$ could assist or replace the oxygen to oxidize the catalyst yielding $\mathrm{MO}_{x}$ species suitable to oxidize the organic compounds in a final step.

Coming back to the oxidation of propene with oxygen, the high activity of $\mathrm{Cr}$-saponite samples is accompanied by the occurrence of high amounts of products of incomplete combustion in the outlet stream, as indicated by the $\mathrm{CO}$ presence. This suggests that the oxygen feed will initially contribute to the chromium oxidation to high oxidation state
$\left(\mathrm{Cr}^{6+}\right)$ and, then, to be reduced to low oxidation states by the organic compounds and/or the reaction intermediates [53]. The reduction of $\mathrm{Cr}^{3+}$ to lower oxidation species should be rather difficult, as has been indicated before in the $\mathrm{H}_{2}$-TPR measurements, requiring high temperatures or a stronger reducing agent in the feed. This should limit the activity, justifying in this case the uncompleted degradation of the hydrocarbon.

In order to gain more information on the influence of chromium phases and of the clay support in the redox behaviour of the catalyst, the same reaction was performed using a $\mathrm{Cr} /$ alumina catalyst as reference (not shown), synthesized in the same way that the clay-based impregnated nitrate sample $\left(\mathrm{Cr}_{\mathrm{Nit}}\right)$. This solid shows the same behaviour that the clay-catalysts indicated before, such as $70 \%$ hydrocarbon conversion and 35\% CO selectivity. This fact suggests that the other elements present in the clay, Fe and $\mathrm{Mn}$, are not involved in the oxidation-reduction process, only the chromium species $\left(\mathrm{CrO}_{x}\right)$ incorporated to the clay are responsible to the activity.

\section{Conclusions}

Treatment of a saponite with polycations of aluminium, chromium or mixtures of the two elements successfully gives rise to intercalated layered solids with high basal spacing. Although the presence of chromium worsen the thermal resistance of the pillared materials, modulating the $\mathrm{Al} / \mathrm{Cr}$ ratio it is possible to obtain solids that adequately combine the stability of alumina-pillared clays and the catalytic ability of chromium. Impregnation of an alumina-pillared saponite support with various chromium-precursors produces, in some cases, the delamination of the layered structure.

The pillared clays and the impregnated materials show high specific surface area and porosity. Their performance for oxidation of propene is very similar independently of the method used for the incorporation of chromium. These results could indicate that the amount of chromium active is the same in all the samples. 


\section{Acknowledgements}

This work was supported by the Spanish Ministry of Education and Science $(M E C)$ and the European Regional Development Fund (FEDER) (MAT2003-01255), and from Junta de Castilla y León. S.A.K. and R.T. acknowledge financial support from $M E C$ through the Ramon-y-Cajal program, and C.B. through the Juan-de-la-Cierva program. Special thanks to J. Soria group for the use of the test catalytic equipment.

\section{References}

[1] D.E.W. Vaughan, Catal. Today 2 (1988) 187.

[2] K. Othsuka, Chem. Mater. 9 (1997) 2039.

[3] J.-F. Lambert, G. Poncelet, Topics Catal. 4 (1997) 43.

[4] H.G. Karge, J. Weitkamp (Eds.), Molecular Sieves-Science and Technology, Synthesis, vol. 1, Springer, Berlin/Heidelberg, 1998.

[5] A. Gil, L.M. Gandía, M.A. Vicente, Catal. Rev.: Sci. Eng. 42 (2000) 145.

[6] Z. Ding, T.J. Kloprogge, R.L. Frost, G.Q. Lu, H.Y. Zhu, J. Porous Mater. 8 (2001) 273

[7] F. Wypych, K.G. Satyanarayana (Eds.), Clay Surfaces-Fundamentals and Applications, Elsevier, Amsterdam, 2004.

[8] M. Thompson, R.E. Connick, Inorg. Chem. 20 (1981) 2279.

[9] J.E. Finholt, M.E. Thompson, R.E. Connick, Inorg. Chem. 20 (1981) 4151.

[10] H. Stünzi, W. Marty, Inorg. Chem. 22 (1983) 2145.

[11] L. Spiccia, W. Marty, Inorg. Chem. 25 (1986) 266.

[12] L. Spiccia, H. Stoeckli-Evans, W. Marty, R. Giovanoli, Inorg. Chem. 26 (1987) 474.

[13] L. Spiccia, W. Marty, R. Giovanoli, Inorg. Chem. 27 (1988) 2660.

[14] G. Johansson, Acta Chem. Scand. 14 (1960) 771.

[15] N. Lahav, U. Shani, J. Shabtai, Clays Clay Miner. 26 (1978) 107.

[16] J.Y. Bottero, J.M. Cases, F. Fiessinger, J.E. Poirier, J. Phys. Chem. 84 (1980) 2933.

[17] K.A. Carrado, S.L. Suib, N.D. Skoularikis, R.W. Coughlin, Inorg. Chem. 25 (1986) 4217.

[18] D.Y. Zhao, Y.S. Yang, X.X. Guo, Zeolites 15 (1995) 58.

[19] R. Toranzo, M.A. Vicente, M.A. Bañares-Muñoz, Chem. Mater. 9 (1997) 1829.

[20] L. Storaro, R. Ganzerla, M. Lenarda, R. Zanoni, A. Jiménez-López, P. Olivera-Pastor, E. Rodríguez-Castellón, J. Mol. Catal. A 115 (1997) 329.

[21] P. Olivera-Pastor, J. Maza-Rodríguez, P. Maireles-Torres, E. RodríguezCastellón, A. Jiménez-López, J. Mater. Chem. 4 (1994) 179.

[22] B.M. Weckhuysen, I.E. Wachs, R.A. Schoonheydt, Chem. Rev. 96 (1996) 3327.

[23] A.Z. Abdullah, M.Z. Abu Bakar, S. Bhatia, J. Chem. Technol. Biotechnol. 80 (2005) 1016.

[24] A. Gil, M.A. Vicente, R. Toranzo, M.A. Bañares, L.M. Gandía, J. Chem. Technol. Biotechnol. 72 (1998) 131.

[25] M. Kang, C. Lee, Appl. Catal. A 266 (2004) 163.

[26] V.F. Tret'yakov, T.N. Burdeinaya, Y.P. Zakorchevnaya, A.G. Zakirova, M.N. Bakhtiyarov, V.A. Matyshak, V.N. Korchak, Kinetic Catal. 46 (2005) 525; T.N. Burdeinaya, V.A. Matyshak, V.F. Tret'yakov, A.G. Zakirova, V.N. Korchak, V.V. Lunin, Kinetic Catal. 48 (2007) 84.
[27] M.A. Vicente, A. Meyer, E. González, M.A. Bañares-Muñoz, L.M. Gandía, A. Gil, Catal. Lett. 78 (2002) 99.

[28] G. Ertl, H. Knözinger, J. Weitkamp (Eds.), Handbook of Heterogenous Catalysis, vol. 1, Wiley-VCH, Weinheim, Germany, 1997.

[29] G. Ertl, H. Knözinger, J. Weitkamp (Eds.), Preparation of Solid Catalysts, Wiley-VCH, Weinheim, Germany, 1999.

[30] C.-C. Chien, W.-P. Chuang, T.-J. Huang, Appl. Catal. A 131 (1995) 73.

[31] I.V. Yentekakis, V. Tellou, G. Botzolaki, I.A. Rapakousios, Appl. Catal. B 56 (2005) 59.

[32] G.W. Brindley, S. Yamakana, Am. Miner. 64 (1979) 830.

[33] C. Volzone, Clays Clay Miner. 43 (1995) 377.

[34] S. Chevalier, H. Suquet, R. Franck, C. Marcilly, D. Barthomeuf, in: M.L. Occelli, H.E. Robson (Eds.), Expanded Clays and Other Microporous Solids, Van Nostrand Reinhold, New York, 1992, pp. 32-46.

[35] L. Bergaoui, J.F. Lambert, R. Franck, H. Suquet, J.L. Robert, J. Chem. Soc. Faraday Trans. 91 (1995) 2229.

[36] L. Bergaoui, J.F. Lambert, M.A. Vicente Rodríguez, L.J. Michot, F. Villiéras, Langmuir 11 (1995) 2849.

[37] M.A. Vicente, M. Suárez, J.D. López-González, M.A. Bañares-Muñoz, Langmuir 12 (1996) 566.

[38] O. Prieto, M.A. Vicente, M.A. Bañares-Muñoz, J. Porous Mater. 6 (1999) 335.

[39] K.S.W. Sing, D.H. Everett, R.A.W. Haul, L. Moscou, R.A. Pierotti, J. Rouquerol, T. Siemieniewska, Pure Appl. Chem. 57 (1985) 603.

[40] F. Rouquerol, J. Rouquerol, K. Sing, Adsorption by Powders and Porous Solids. Principles, Methodology and Applications, Academic Press, London, 1999.

[41] G. Horvath, K. Kawazoe, J. Chem. Eng. Jpn. 16 (1983) 470.

[42] B. Casal, J. Merino, E. Ruiz-Hitzky, E. Gutiérrez, A. Alvarez, Clay Miner. 32 (1997) 41.

[43] A. Gil, M.A. Vicente, L.M. Gandía, Micropor. Mesopor. Mater. 34 (2000) 115.

[44] M.A. Vicente, R. Toranzo, M.A. Bañares-Muñoz, E. Rodríguez, An. Quím. 94 (1998) 136.

[45] F.M. Labajos, V. Rives, Inorg. Chem. 35 (1996) 5313.

[46] M. del Arco, D. Carriazo, C. Martín, A.M. Pérez-Grueso, V. Rives, J. Solid State Chem. 178 (2005) 3571.

[47] B.M. Weckhuysen, L.M. de Ridder, P.J. Grobet, R.A. Schoonheydt, J. Phys. Chem. B 99 (1995) 390.

[48] Z. Zhu, Z. Chang, L. Kevan, J. Phys. Chem. B 103 (1999) 2680.

[49] K.T. Ranjit, L. Kevan, J. Phys. Chem. B 107 (2003) 2610.

[50] J.M. Goupil, J.-F. Hemidy, D. Cornet, J. Chim. Phys. 73 (1976) 431.

[51] Z. Zhu, M. Hartmann, E.M. Maes, R.S. Czernuszewicz, L. Kevan, J. Phys. Chem. B 104 (2000) 4690.

[52] C. Belver, M.A. Vicente, A. Martínez-Arias, M. Fernández-García, Appl. Catal. B 50 (2004) 227.

[53] J.M. Yáñez-Limón, J.F. Pérez-Roblez, J. González-Hernández, R. Zamorano-Ulloa, D. Ramirez-Rosales, Thin Solid Films 373 (2000) 184.

[54] V.R. Choudhary, S. Banerjee, S.G. Pataskar, Appl. Catal. A 253 (2003) 65.

[55] A.Z. Abdullah, M.Z. Abu Bakar, S. Bhatia, J. Hazard. Mater. B 129 (2006) 39.

[56] V.R. Choudhary, G.M. Deshmukh, Chem. Eng. Sci. 60 (2005) 1575.

[57] P. Mars, D.W. van Krevelen, Spec. Sup. Chem. Eng. Sci. 3 (1954) 41.

[58] F. Bertinchamps, M. Treinen, N. Blangenois, E. Mariage, E.M. Gaigneaux, J. Catal. 230 (2005) 493. 